\title{
International political economy and future fertility trends
}

\author{
Alícia Adserà̀ $^{1, *}$
}

When I was asked what would be the most important factor likely to influence fertility in the near future, my first inclination was to focus on countries experiencing very low fertility, particularly European and East Asian nations. Out of the multiple factors that are bound to have large effects on childbearing behaviour in low-fertility advanced nations - and, eventually, in less developed settings as well - I wish to highlight three examples. First, the continuous postponement of first births (and the associated challenges for fecundity), combined with the growing role of artificial reproduction techniques (ART) and genetic manipulation, could raise new ethical issues surrounding births. Second, a deepening of the current structural changes in the labour market, which have led to reductions in jobs in mid-skilled occupations and increases in more unstable positions at the low end of the market, may lead to a further flattening or even a reversal of the educational gradients of fertility (Adserà 2017). Third, the digitalisation of society, which is characterised by the dominance of social media and the internet as an information source, may affect childbearing decisions differentially across socioeconomic groups and origins. Indeed, recent research suggests that the internet is already having a significant effect on fertility patterns; although determining which mechanisms are at work in this association remains an open research agenda (Billari et al. 2019).

Nevertheless, as policy efforts to raise fertility in low-fertility countries have shown, the margins for changing fertility levels in those settings are limited (Gauthier 2007). When looking at the current levels across the world, we can see that the largest potential margins of change in overall fertility levels are in Sub-Saharan Africa. Table 1 shows UN Population Division estimates of the total fertility rate by Sustainable Development Goal regions. Africa, Western Asia, South Asia, and Central Asia are the only regions that are expected to end this decade with fertility rates above replacement level and, within those regions, Sub-Saharan Africa is a clear outlier, with an average total fertility rate of close to five.

\footnotetext{
${ }^{1}$ Princeton School of Public and International Affairs, Princeton University, Princeton, USA

${ }^{*}$ Correspondence to: Alícia Adserà, adsera@princeton.edu
} 
Table 1:

Total fertility rate by Sustainable Development Goal regions

\begin{tabular}{lcccc}
\hline $\begin{array}{l}\text { Sustainable Development } \\
\text { Goal (SDG) regions }\end{array}$ & $\mathbf{1 9 5 0 - 1 9 5 5}$ & $\mathbf{1 9 7 5 - 1 9 8 0}$ & $\mathbf{2 0 0 0 - 2 0 0 5}$ & $\mathbf{2 0 1 5 - 2 0 2 0}$ \\
\hline Sub-Saharan Africa & 6.51 & 6.78 & 5.64 & 4.72 \\
Northern Africa and Western Asia & 6.57 & 5.75 & 3.20 & 2.93 \\
Central and Southern Asia & 6.00 & 5.27 & 3.21 & 2.41 \\
Eastern and South Eastern Asia & 5.69 & 3.30 & 1.82 & 1.83 \\
Latin America and the Caribbean & 5.83 & 4.44 & 2.49 & 2.04 \\
Australia/New Zealand & 3.27 & 2.02 & 1.80 & 1.84 \\
Europe and North America & 2.80 & 1.92 & 1.60 & 1.66 \\
\hline
\end{tabular}

Note: World Population Prospects 2019. File FERT/4: Total fertility by region, subregion, and country, 1950-2100 (live births per woman). Department of Economic and Social Affairs, U.N. Population Division.

In an excellent paper on the fertility transition in Africa, Bongaarts (2017) examined the distinct position of African countries in this process, which was previously mentioned by Caldwell et al. (1992). The fertility transition in African countries happened later (around the mid-1990s) than it did in other developing countries. Moreover, the transition in African countries occurred at lower levels of development than it did elsewhere, and it progressed at a very slow pace. As Bongaarts' (2017) estimates show, African countries continue to have both lower contraceptive use and higher desired fertility than other similarly developed countries.

Among the multiple coexisting factors that account for this distinct position, I have chosen to focus in this short note on how political stability and the international political economy may affect African fertility (and global fertility), both currently and in the near future. I briefly discuss three pathways: (1) the impact of the region's violence and weak governance on the pace of its fertility transition; (2) the effect of both immigration policies and the size of the welfare state in the major destinations of African migrants on migrant integration and, arguably, on the fertility trends in those destinations themselves; and (3) the influence of remittances and return migration (whether permanent or temporary) on fertility norms in the origin countries.

\section{Political institutions, leadership, and violence in high-fertility countries}

Traditional pronatalist social, economic, and cultural practices have been invoked to explain why fertility remains so high in many Sub-Saharan countries, and why it has been decreasing so slowly since the start of the demographic transition in 
the mid-1990s in many of these countries (Caldwell et al. 1992; Bongaarts 2017). Even though Bongaarts (2017) notes that relatively low rates of contraception use coexist with a larger desired family size in Sub-Saharan Africa, there is evidence of a substantial unmet need for contraception in the region (Bongaarts and Casterline 2012). As studies conducted in a handful of countries have shown, national support for family planning and political will among top policy-makers are crucial to the success of efforts to reduce fertility (Cleland et al. 2006). May (2017) has described in detail the lack of leadership among some political elites around issues of family planning, as they often conform to their constituencies' existing pronatalist views.

It is also clear that in some of these countries, weak governance hampers not just access to contraception, but, more importantly, human capital investments (both in education and health) that are associated with lower morbidity and mortality, less risky behaviour, and higher levels of agency among women (Lutz and Skirbekk 2014). In most African societies, contraceptive demand is greater and the desired family size is smaller among the more educated classes (Bongaarts 2010).

The ongoing political instability, wars, and violence in some parts of the region limit the territorial access of both public and private organizations seeking to provide family planning and health services, and to improve the educational infrastructure. In addition, the people who have been displaced as a result of this instability particularly those in refugee camps - have traditionally been underserved. In some contexts, wars and forced displacement have led to earlier marriages. While the aim of such arrangements is ostensibly to protect young girls, early marriage can have a detrimental impact on women's human capital formation, and lead to early fertility.

Whether the region enters into a virtuous circle of higher human capital investment, which would likely speed up a fall of fertility rates, will depend on the extent to which political instability decreases and political leadership and governance improve in the coming years.

\section{Immigration policies and the welfare state in migrant destinations}

Confronted with low fertility and rising dependency ratios, most advanced countries face a few policy options to sustain their relatively generous welfare states. Boosting fertility rates in these countries via direct policies has proven difficult (Gauthier 2007). Alternatively, policies designed to increase labour productivity (via capital deepening and improved skills) or adjust the generosity of the welfare state have sparked long-running debates. Finally, larger migration flows could temporarily reverse the trend in dependency ratios and rejuvenate the population. The demographic and economic pressures in Sub-Saharan Africa in particular are generating a large pool of potential migrants.

Policies in the receiving countries will determine the size of migration inflows, as well as their demographic and political consequences. On the one hand, 
well-integrated migrants who contribute to the productivity of the receiving economy should improve the ability of the country to sustain welfare policies, including family policies that support fertility. On the other hand, how natives perceive the impact of the new migrant flows into their economies will affect the political economy of the receiving country. Fears of competition in the labour market or concerns about the dilution of national values may cause protectionism and populism to rise. As migration increases, political support for welfare programs may decline if natives are afraid that migrants will overuse these services (Senik et al. 2009). Thus, there is a danger that a race-to-the-bottom dynamic will emerge that both hampers the ability of newcomers to integrate, and threatens existing family policies that ease work-family trade-offs for natives in the destination countries. As part of ongoing research, Adserà et al. (2019) have found that especially among high-skilled migrants, having access to private employment in the destination country, rather than having access to welfare benefits, largely explains the recent migration flows into the OECD (Organization for Economic Co-operation and Development) countries.

How well migrants integrate into society in general - whether through intermarriage or the adoption of local social norms - is contingent on their economic opportunities, as well as on natives' attitudes. To date, there is general evidence that the fertility levels of migrants and natives are converging, albeit with some heterogeneity across origin groups. Kulu et al. (2019) have provided one of the most recent overviews of the research in this area. If it is indeed the case that migrant fertility tends to adapt to local trends within one generation or less, it is unlikely that higher levels of migration alone will boost fertility rates in low-fertility countries. Sobotka (2008) has shown that the overall impact of migrant populations on fertility rates in European countries has not been as large as a casual reading of some press reports or political discourses would suggest. Moreover, the degree to which migrants adapt to social norms and fertility behaviour in the destination country will have a bearing on the norms that they transmit to their peers in the country of origin, as I explain below.

\section{Reverse development and fertility}

Both remittances and ideas brought back into the country by natives with migration backgrounds may speed up fertility changes in the countries of origin. Financial remittances constitute a large share of GDP in many source countries with a large diaspora. These transfers are instrumental to smoothing consumption and increasing savings in those countries. The reduction of uncertainty and the overall economic improvement in remittance recipient households (and communities) should lessen pressures on families to put children to work, and should encourage educational investments.

In addition to financial remittances, social remittances in the form of transfers of information, skills, and social capital from receiving communities are another 
important contributor to development in the sending countries (Levitt 1998). Both return migrants and transnational migrants play an important role in the transmission of new values to their communities of origin. In recent years, cheap and accessible communication technologies have facilitated the emergence of the transnational migrant as an individual who builds networks of economic and social connections with his/her country of origin while settled abroad (Portes 1999). Social remittances should facilitate the convergence of social norms, gender roles, and women's empowerment in the form of higher female labour market participation and educational levels. Having first-hand information about family planning from peers should help lower barriers to contraception uptake by alleviating fears of experiencing social disapproval and side effects when using contraception, and by easing withincouple negotiations (Cleland et al. 2006). Furthermore, calls for stronger democratic values in source countries that are informed by the experiences of the countries' migrants in their receiving communities may persuade authoritarian regimes to improve their policies in areas such as human capital formation.

Beine et al. (2013) show some degree of convergence in fertility levels between many sending countries and major destinations of their migrants. We should expect this transmission process will increase further via the use of social media the internet and continuous contact with migrant relatives.

Overall, the current trends in the international political economy seem to offer more opportunities than threats for the progress of women. Provided there is a reduction in the level of violence and improvements in governance that boost human capital investment in high-fertility countries, as well as a gradual convergence in gender norms across the globe, we should observe an increase in the pace of fertility decline in high-fertility regions among the more educated younger cohorts - and, as a result, a decrease in average fertility worldwide.

\section{References}

Adserà, A. 2017. Education and fertility in the context of rising inequality. Vienna Yearbook of Population Research 15: 63-92. https://doi.org/10.1553/populationyearbook2017s063

Adserà, A., J. Palmer and M. Pytlikova 2019. Border controls, benefits, and rights: How states shape migration patterns in a world of multiple origins and destinations. Mimeo, Princeton University.

Beine, M., F. Docquier and M. Schiff 2013. International migration, transfer of norms and home country fertility. The Canadian Journal of Economics/Revue canadienne d'économique 46(4): 1406-1430. https://doi.org/10.1111/caje.12062

Billari, F. C., O. Giuntella and L. Stella 2019. Does broadband Internet affect fertility? Population Studies 73(3): 297-316. https://doi.org/10.1080/00324728.2019.1584327

Bongaarts, J. 2010. The causes of educational differences in fertility in Sub-Saharan Africa. Vienna Yearbook of Population Research 8: 31-50. https://doi.org/10.1553/ populationyearbook2010s31 
Bongaarts, J. 2017. Africa's unique fertility transition. Population and Development Review 43(S1 Supplement: Fertility Transition in Sub-Saharan Africa): 39-58. https://doi.org/10. 1111/j.1728-4457.2016.00164.x

Bongaarts J. and J. Casterline 2012. Fertility transition: Is sub-Saharan Africa different? Population and Development Review 38(Supplement): 153-168. https://doi.org/10.1111/j. 1728-4457.2013.00557.x

Caldwell, J. C., I. O. Orubuloye, P. Caldwell 1992. Fertility decline in Africa: A new type of transition? Population and Development Review 18(2): 211-242. https://doi.org/10.2307/ 1973678

Cleland, J., S. Bernstein, A. Ezeh, A. Faundes, A. Glasier and J. Innis 2006. Family planning: The unfinished agenda. Lancet 368(9549): 1810-1827. https://doi.org/10.1016/ S0140-6736(06)69480-4

Gauthier, A. H. 2007. The impact of family policies on fertility in industrialized countries: a review of the literature. Population Research Policy Review 26(3): 323-346. https: //doi.org/10.1007/s11113-007-9033-X

Kulu, H., N. Milewski, T. Hannemann and J. Mikolai 2019. A decade of life-course research on fertility of immigrants and their descendants in Europe. Demographic Research 40(46): 1345-1374. https://doi.org/10.4054/DemRes.2019.40.46

Levitt, P. 1998. Social remittances: Migration driven local-level forms of cultural diffusion. International Migration Review 32(4): 926-948. https://doi.org/10.1177/ 019791839803200404

Lutz, W. and V. Skirbekk 2014. How education drives demography and knowledge informs projections. In World population and human capital in the twenty-first century, eds W. Lutz, W. P. Butz and S. KC, 14-38. Oxford University Press.

May, J. F. 2017. The politics of family planning policies and programs in sub-Saharan Africa. Population and Development Review 43(S1 Supplement: Fertility Transition in Sub-Saharan Africa): 308-329. https://doi.org/10.1111/j.1728-4457.2016.00165.x

Portes, A. 1999. Conclusion: Towards a new world - the origins and effects of transnational activities. Ethnic and Racial Studies 22(2): 463-477. https://doi.org/10.1080/ 014198799329567

Senik, C., H. Stichnoth and K. Van der Straeten 2009. Immigration and natives' attitudes towards the welfare state: Evidence from the European social survey. Social Indicators Research 91(3): 345-370. https://doi.org/10.1007/s11205-008-9342-4

Sobotka, T. 2008. The rising importance of migrants for childbearing in Europe. Demographic Research 19(9): 225-248. https://doi.org/10.4054/DemRes.2008.19.9

Open Access This article is published under the terms of the Creative Commons Attribution 4.0 International License (https://creativecommons.org/licenses/by/4.0/) that allows the sharing, use and adaptation in any medium, provided that the user gives appropriate credit, provides a link to the license, and indicates if changes were made. 